\title{
THE LEGALITY OF AMERICAN MILITARY INVOLVEMENT IN VIET NAM: A BROADER PERSPECTIVE
}

\author{
NEILL H. ALFORD, JR.*
}

WE are forcefully reminded, from time to time, of the presence in Western tradition of an impulse for transcendence and perfection. Goals thought to support a "right" order of humanity are religiously pursued, while limits upon the means chosen to attain them are frequently ignored. Our unique American experience has reinforced this Western impulse and critics of United States policy in Viet Nam fear that we are once again resorting to violence to force our concepts of an ideal society upon others. ${ }^{1}$

There is an immediate need for examination of the assumptions which support current American foreign policy. This examination will be difficult. While our idealism often burgeons into the pursuit of sentimental and perhaps unattainable goals in foreign affairs, this idealism is essential to cement together the disparate elements of our nation. Only recently have we become conscious of the degree of strain within the United States and of the importance of idealism in keeping the country from bursting asunder. It is futile to consider abandoning idealism in the conduct of our foreign policy, because idealism is a cultural trait too well seated to be excised without destruction of the whole social organism.

Most critics of our policy in Viet Nam have spoken from a philosophy as idealistic as that held by supporters of that policy. Both sides in the debate appear to have in mind ideal societies; neither seems overly disturbed by the means to attain them. Thus, the debate over legal aspects of the United States policy in Viet Nam has been shunted off to the side and ignored by all except law professors, lawyers and others with an interest in international and constitutional law. It is frequently said that law "has nothing to do" with the United States action in Viet Nam or that the problem is simply too serious for legal issues to be significant. This position involves assumptions about law as erroneous as they are facile.

- Professor of Law, University of Virginia; B.A. 1940, The Citadel; LL.B. 1947, Univ. of Virginia.

1. See, e.g., E. O. Sthllaian and W. Pfaff, The Polmtos of Hysterda (19G4) and POWER AND IMIPOTENCE (1966). 
Mr. Kennan, ${ }^{2}$ Messrs. Stillman and Pfaff ${ }^{3}$ and others speak of law in terms of rules for resolving conflict between individuals or communities. Mr. Kennan, in particular, finds "the legalistic-moralistic" approach to international problems "the most serious fault of our past policy formulation." 4 He deplores efforts to force patterns of conflict into legalistic categories. But these criticisms ignore the constitutive functions of law. Legal processes are orderly means by which we agree upon community goals and estimate the likelihood of their attainment. More important, legal processes can build and strengthen institutions such as the United Nations which encourage the diffraction of coercion and its projection on a verbal level.

\section{The Arguments of the State Department Memorandum}

The assumptions underlying the positions of Messrs. Kennan, Stillman and Pfaff may result in inattention to the State Department Memorandum on Viet Nam. ${ }^{5}$ Yet the Memorandum is an official landmark. It develops in detail arguments based on self-defense and collective self-defense, which received little official treatment in the debates following the Cuban Quarantine of $1962 . .^{\circ}$ An analysis of the "legal response" to the "legally puzzling" "War of National Liberation" will doubtless have an effect upon official thought in the United States similar to the effect in the early 20th century of Clark's memorandum on protecting American citizens abroad ${ }^{7}$ and the response by

2. Kennan, American Diplomacy 1900-1950 95-101 (1951).

3. E.g., Stlllman and Pfaff, Power and Impotence 28.30 (1966).

4. Kennan, supra note 2 , at 95.

5. The Legality of United States Participation in the Defense of Viet-Nam, 54 DEP'T State Buld. 474 (1966) [hereinafter cited as Memorandum].

6. Official or semi-official statements were made by Legal Adviser Chayes and then Deputy Legal Adviser Meeker in the debates following the Cuban Quarantine of 1962. See Chayes, The Legal Case for U.S. Action on Cuba, 47 DEP'T STATE BULl. 763 (1962); Law and the Quarantine of Cuba, 41 Forergn AfFalrs 550 (1963); Remarls, 1969 Proc. AM. Soc. INT'L L. 10; and Meeker, Defensive Quarantine and the Law, 57 AM. J. INT'L L. 515 (1963). The official arguments then pivoted on collective action by virtue of the resolution of October 23, 1962 by the Council of the Organization of American States. Arguments based upon self-defense or collective self-defense were not then pressed by these spokesmen, although energetically put forward by others. E.g., Mallison, Limited Naval Blockade or Quarantine Interdiction: National and Collective Defense Claims Valid Under International Law, 31 GEo. WASH. L. REv. 335 (1962). A glimmer of the arguments advanced by the State Department officials in the debates following the Quarantine still remains in the Memorandum of March 4, 1966, with reliance upon action under Article IV of the SEATO Treaty. See Memorandum 480-81.

7. Clark, Right to Protect Citizens in Foreign Countries by Landing Fonces (DC. partment of State, Division of Information, Series M, No. 14, Oct. 5, 1912; reprinted in Department of State Publications, No. 5 1934). 
Secretary Hay to the Wilson memorandum on de facto blockades by insurgents. ${ }^{8}$

The author of this comment is in general agreement with the points made in this Memorandum in response to criticism of the legal grounds for the policy of the United States in Viet Nam. But unfortunately the Memorandum is responsive to attacks based upon an extremely narrow conception of law. This, in turn, has caused the Memorandum to be narrow in conception, to stress things that perhaps should not be stressed, to de-emphasize things that probably should be emphasized. Without an attempt fully to document the counter-attack to criticism of United States policy in Viet Nam, which was well done in the Memorandum and which will be done even more completely in other articles to be published in the near future, ${ }^{9}$ the major arguments of critics of the United States policy in Viet Nam will be considered first with observations on the State Department answers to these arguments. Thereafter a somewhat broader approach than that adopted by the State Department will be suggested.

Arguments by critics based upon customary international law and upon Articles 51 and 2(4) of the United Nations Charter require detailed attention because of uncertainties in general community policy in these areas. To the extent, however, that the critics argue that South Viet Nam is not a state, their position is wholly untenable.

It has been urged, for example, that South Viet Nam (the Republic of Viet Nam) is not a state but an insurgent area resisting its de jure government in Hanoi. It is unfortunate that the State Department Memorandum does not take a more positive position on this point. The Memorandum suggests that South Viet Nam might lack some of the attributes of statehood, but that United States policy is still defensible because it supports the demarcation line established in the Geneva Accords of 1954 (though violated by North Viet Nam). ${ }^{10}$

8. U.S. NAVAL WAR COLLEGE, INTERNational LAW StTuAtions 79.83 (1902).

9. See Deutsch, The Legality of the United States Position in Viet Nam, 52 A.B.A.J. 436 (1966) and J. N. Moore \&: J. L. Underwood, The Lawfulness of United States Assistance to the Republic of Viet Nam (unpublished manuscript).

10. The State Department Memorandum appears to take the position that the Accords are still viable, although the "systematic violation . . . by North Viet Nam justi. fied South Viet Nam in suspending compliance with the provision controlling entry of foreign military personnel and military equipment," and "there may be some question whether South Viet Nam was bound by ... [the] election provisions." Memorandum 483. There were four interrelated documents-a cease-fire agreement for Laos, Cambodia and Viet Nam and an unsigned "Final Declaration." These documents may be found in Senate Comm. on Foreign Relations, 89Th Conc., 2d Sess., Background Information Relating to Southeast Asia and Viet Nam 36-39 (Comm. Print 1966). The legal status 
As pointed out in the Memorandum, sixty states have recognized South Viet Nam (eight of these are de facto recognitions). The General Assembly has, on two occasions, affirmed the qualifications of South Viet Nam for admission to the United Nations. ${ }^{11}$ In both instances the Security Council failed to recommend admission because of the veto of the Soviet Union. ${ }^{12}$ But the Soviet Union did not suggest as a reason that South Viet Nam was not a state. Instead, the Soviet Union seemed to assume state status.

South Viet Nam is a member of and is active in more of the specialized agencies of the United Nations than the Soviet Union. It has participated in forty-eight international conferences.

Although South Viet Nam has relied on French and, currently, United States military assistance, it maintains armed forces for defensive purposes larger than those of most of the members of the United Nations. While its government has relied upon United States assistance in maintaining order, its governmental policies have been to a substantial degree free from United States influence.

The only argument which might be offered against the state status of South Viet Nam is based upon the Geneva Accords of 1954..13 It has sometimes been assumed that these Accords require a single Vietnamese state-but nothing in the Accords suggests more than an expectation that a vote would decide this issue, and no requirement was included that the votes of both South and North Vietnamese be counted together on this question.

Although the Memorandum seems to suggest that the United States continues to regard parts of the Geneva Accords of 1954 as viable, it is difficult to ascribe to this ambiguous and ill-conceived transaction a force which would deprive a community of state status at any time in the future if this community satisfies such requirements as other states impose to determine state status. These requirements seem to be that (1) the community have a reasonable probability of permanent iden-

of the "Final Declaration" is quite equivocal and probably the deference to it now shown springs from the will-o-the-wisp of popular elections mentioned in detail in the declaration and casually in the cease-fire agreements. The provisional nature of those Accords relating to Viet Nam, in view of the radical changes in conditions since their dubious beginning, should be a basis for disregarding them altogether, although the State Department may still value the demarcation line and several other provisions of the Accords which it would desire respected.

11. U.N. Gen. Ass. OfF. Rec. 11th Sess. 1017 B(XI) (A/PV.663) (Feb. 28, 1957); U.N. GEN. Ass. OFF. REc. 12th Sess. 1144 B(XI) (A/PV.709) (Oct. 25, 1957).

12. U.N. Security Council OfF. Rec. (S/PV.790) (Sept. 9, 1957); U.N. SEcurtry CounCIL OfF. Rec. (S/PV.843) (Dec. 9, 1958).

13. See note 10 supra. 
tity; (2) that it have an organized government; (3) a defined territory; and (4) sufficient independence to conduct its foreign relations. ${ }^{1 *}$ Other requirements might be imposed in special contexts; but undoubtedly other states share an expectation that South Viet Nam is a state.

Since arguments that South Viet Nam is not a state have no weight, the main thrust of the critics' attack upon the United States policy has been based on Article 51 of the United Nations Charter, which preserves members' rights to self-defense in cases of "armed attack." 15 The provisions of Article 51 are ambiguous and were intentionally made ambiguous to permit states to take shelter under the cover of their collective or regional defense systems if the United Nations proved impotent as a peace enforcement institution. Views also differ concerning the precise limits of the customary doctrines of self-defense and collective self-defense. This complicates the interpretation of Article 51.

One point does seem certain. No basis exists for assuming that all defensive measures contemplated by Article 51 are keyed to "armed attacks," or that an "armed attack," as contemplated by Article 51, occurs only when missiles are launched or forces deployed and set in motion against an adversary. Under conditions of modern military action, an "armed attack" may be regarded as a process and not solely a single hostile offensive event.

Another certain point is that Article 51 does not deprive non-members of their right to self-defense. It is quite doubtful that the parties to the Charter could impose disabilities or obligations upon nonmembers. Members certainly could agree to act against non-members, as they appear to have done in Article 2(6) of the Charter, or they could impose conditions upon a non-member involing the aid of United Nations organs, as in Article 35(2) of the Charter. But it is not accepted that parties to the Charter can impose any other restraints upon the action of non-members. The State Department Memorandum suggests international custom could be affected by the continued

\footnotetext{
14. See BRIERLy, The LAW of NATIONS 122-24 (4th ed. 1949) where these requirements are briefly and conveniently discussed.

15. Article 51:

Nothing in the present charter shall impair the inherent right of individual or collective self-defense, if an armed attack occurs against a member of the organization until the Security Council has taken the measures necessary to maintain international peace and security. Measures taken by members in the exercise of this right of selfdefense shall be immediately reported to the Security Council and shall not in any way affect the authority and responsibility of the Security Council under the present charter to take at any time such action as it may deem necessary in order to maintain or restore international peace and security.
} 
application of Charter provisions, and this custom could thus affect the obligations of non-members-however, this proposition has received no general acceptance. ${ }^{18}$

Thus, a non-member retains whatever rights of self-defense or collective self-defense it had prior to the Charter unless changes in international custom have actually conditioned these "rights" in new ways. Certainly a provision expressly relating to members in Article 51 should not be taken by inference to refer to non-members as well, and especially not to deny to non-members rights of self-defense or collective self-defense which members retain despite the provisions of the Article. Quite clearly, South Viet Nam can act to defend itself against attacks by neighbors from the North.

The question remains of what restraints exist under the Charter upon United States assistance. Records of Committees engaged in preparatory work on Articles 51 and 2(4) indicate they intended to retain the customary doctrine of self-defense for members without requiring an "armed attack" as a precondition. ${ }^{17}$ The supervisory structure-the institutions developed for community judgment in the Security Council and General Assembly-could determine whether selfdefense or collective self-defense was properly invoked in any given situation; and Article 51 was not expected to stand independently as the only guideline for protective action. The State Department Memorandum describes its operation correctly as a "saving clause."18 There is an additional requirement that the defensive measures be reported to the Security Council and there is also implied recognition of "collective self-defense" arrangements that might not be regional arrangements as described in Chapter VIII.

At the time of Dumbarton Oaks and the San Francisco Conference, an "armed attack" was generally understood as a process by which a state sought the initiative by a violent exercise of physical power. Survival of an adversary under such an attack required ability on the part of the adversary to strike at the source of power of the attacker. A passive defensive posture had proven utterly futile in World War II. But a counterstrike of the type required might violate Article 2(4)

16. See Memorandum $476 \mathrm{n} .3$ for support of the proposition that "it seems entirely appropriate to appraise the actions of South Viet-Nam in relation to the legal standards set forth in the United Nations Charter."

17. 12 U.N. Conf. INT'L ORG. Docs. 68-82; Report of Committee 1 to Commission 1, 6 U.N. CoNF. INT'L ORG. Docs. 446, 459; Verbatim Minutes of Fifth Meeting of Commission I, 6 U.N. Conf. INT'L ORG. Docs, 202, 204.

18. Memorandum 475. 
and would certainly serve as a link in the chain of escalation of violence which the Security Council was designed to break.

The draftsmen of Article 51 probably intended to limit only the armed counterstrike which would otherwise be in violation of Article 2(4) and in no way to preclude other exercises of power, even though by military force, consistent with Article 2(4). In order for any organization, such as the United Nations, to perform its security functions, member states would certainly have to enjoy rights of self-defense and collective self-defense as broad as those of non-members.

The United States action in Viet Nam is directed principally to the preservation of order in South Viet Nam. No recognized spokesman for South Viet Nam has contended that the territorial integrity or political independence of South Viet Nam has been violated by the United States. The air raids against supply routes and training installations in North Viet Nam are in direct support of the South Viet Nam operations. No one has ever contended that either the United States or South Viet Nam has aspirations affecting the territorial integrity and political independence of North Viet Nam. The United States simply acts to frustrate an escalating aggression by North Viet Nam, which conflicts with the principles stated in Article 2 of the Charter. The United Nations, however, is not prepared to act to counter this aggression under Article 2(6), because of the Soviet veto in the Security Council and the difficulty of organizing action in the General Assembly where the United States lacks the backing of major Western powers who find the anti-Western features of the Vietnamese war an embarrassment in their relations with their former colonies.

Just as Article 51 of the Charter does not preclude a broad spectrum of military action so long as this action is consistent with Article 2(4), the Charter does not limit a member's participation in collective defense arrangements to "members of the club." The "regional arrangements," for example, seem clearly to embrace the participation of non-members:-indeed, like membership in the specialized agencies, participation in regional security arrangements provides an opportunity for contributions by non-members to world security when their membership is denied for reasons unrelated to the qualifications expressed in Article 4 of the Charter.

It should be observed also that there are two opportunities for collective defense in addition to the commitments undertaken by members to support action by the United Nations. These are the Regional Arrangements under Article VIII and "collective defense arrange- 
ments" implied under Article 51.10 If there is any requirement of territorial contiguity and cultural identity for Regional Arrangements, the United States has territory in the area of SEATO and a substantial cultural identity with the people of that area. Obviously it has security interests in common with SEATO members and areas brought within the protection of SEATO that will support a "collective defense agreement" with South Viet Nam under Article 51.

When critics of the United States action feel they cannot prevail by arbitrary and unnecessarily restrictive interpretations of Article 51, they then contend that the action the United States pursues in South Viet Nam is not permitted by international legal custom. The basis of this contention is an erroneous assumption of fact-that the strife in South Viet Nam is internal (or was internal until the United States commenced its assistance). There are at least three revolutions going on in South Viet Nam. George A. Carver has recently analyzed two of them:20 (1) a battle for power between a French-educated, foreignoriented class and a militantly "Vietnamese" group-by which the United States periodically finds its military efforts embarrassedbasically a social revolution; and (2) a North Vietnamese directed insurgency-which is the one the United States aids in suppressing. There is a third, an anti-Western revolution, currently almost dormant in South Viet Nam, but which will certainly flare up to complicate relations between the United States and Afro-Asians in the future.

But even assuming that the strife in South Viet Nam was indigenous, which it does not appear to be, there seems little in international legal custom which would preclude the United States from acting in conjunction with a friendly government to maintain internal order. The publicists are divided on the point, most taking the position that the government can be assisted.

\section{A Broader Perspective}

The legal critics of American involvement in Viet Nam have neglected the broader functions of law. Regrettably the Memorandum, by attempting to meet the legal critics of American involvement headon, have adopted their narrow perspective and neglected the broader functions of law. Why should we discuss the conflict in Viet Nam in terms of a "who did it first" analysis? That approach was meaningful to the Justices in Eyre of Edward I when dealing with a fracas between

19. The distinction between these possible defensive arrangements is clearly made in McDevitt, The U.N. Charter and the Cuban Quarantine, 72 JAG J. 71 (1969).

20. Carver, The Faceless Viet Cong, 44 Foreign Afralrs 347 (1966). 
peasants, and helps us to analyze problems which can be solved by shifting wealth from one person to another. But the values involved in Viet Nam cannot be converted into cash equivalents. Stability must be attained in South Viet Nam so that the South Vietnamese may manage their affairs without chronic violence. Yet who wins the war in Viet Nam may have little to do with the establishment of a viable system of world order; while how and what we and others think about our uses of power there will have a lot to do with it. Law has an important, although not exclusive, role in defining attainable goals, shaping how we think about power and other values, coordinating action to attain goals, and emphasizing the use of persuasion rather than violence to alter or satisfy demands. The "conflict resolving" features of law are least relevant to the war in Viet Nam.

The Memorandum does not clarify what the policies of the United States may be, beyond "pushing out an invader who has attacked." This hugs rather closely the formula of Article 51 of the United Na. tions Charter.

One can conceive of other possible policies which support our action. Red China is being excluded, at least temporarily, from the "rice bowl of Asia"; Red Chinese armies cannot turn against Europe or the rest of Asia without added food supplies, even assuming these troops can "live off the land" more effectively than Western armies. Thanks to effective action in Viet Nam, Japan need not look for markets in a wholly communized Asia-with the shift in political perspective this would entail. And the American stand in Viet Nam is a major reason why the Indonesian military was prepared to resist a communist coup.

The problems of South Viet Nam are, in microcosm, those of the underveloped world. Western ideas-democracy and communismclash in the minds of people whose cultures have been sapped by the intellectual imperialism of the West. It may therefore also be a United States policy to seek answers or palliatives to the problems of the South Vietnamese which have broader applications. ${ }^{21}$

Whether or not such policy goals exist is unclear. Apart from "pushing out the invader," the goal which the Memorandum stresses, emphasis has been given lately to insuring "self-determination" by the South Vietnamese. Critics of United States policy quote different scripture for their faith in self-determination-either Wilsonian rhetoric, Buddhist demands for a referendum, or the ill-considered and obsolete

21. See Lansdale, Diet Nam: Do Whe Understand Revolution?, 43 FoneICN AfFairs 75 (1964) which stresses the need for imaginative civilian action, to create conditions favorable to a "true" (non-Communist) Vietnamese revolutionary cause. 
provisions of the 1954 Geneva Accords-but all consider self-determination (translated as determination by ballot) basic to a "decently ordered" society. Their demands have been accommodated in United States policy statements. American action is portrayed as an effort to secure self-determination for a harassed people, who otherwise would be denied its blessings.

Unfortunately, no significant vote can be taken outside the urban areas of South Viet Nam, and the countryside, containing a popular majority, is controlled at least intermittently by the Viet Cong. A vote there, until Viet Cong control is broken, would be as unreliable a statement of opinion as the one-candidate elections of "people's democracies." To uproot the Viet Cong, the United States thus stumbles onto a platform of "enfranchisement by bombardment"-repellent to all who think about it.

The Memorandum reflects some of this emphasis on an expression of free will in South Viet Nam by relying heavily upon the continuing consent of the "Government of South Viet Nam" to our assistance. This stems in turn from the "who did it first" analysis we observed earlier. But this concession encourages the assumption that if some group claiming governmental status in Viet Nam-perhaps containing members of regimes with which we have previously dealt-asked the United States to leave, we would fold our tents and steal away. The matter is not so simple.

If we were asked to leave, we would first have to determine whether the government making the request expressed the wishes of so many South Vietnamese that our continued presence would exacerbate friction rather than promote eventual stability. Critics have argued that the present South Vietnamese government is unrepresentative. This contention is based upon factual allegations that simply cannot be determined with any accuracy until stability is restored.

In any event, withdrawal is not a subject for unilateral action by the United States. Several of our SEATO allies have forces in Viet Nam. Approximately 40,000 South Korean troops are there now. Although a decision by the United States to withdraw would cause our allied participants to withdraw also, joint participation would seem to necessitate joint consultation, and great deference to the wishes of states with immediate security interests in the outcome of the war. South Viet Nam is not "estopped" from requesting us to leave, but our military involvement there has reshaped our strategic posture. Our power to strike is more flexible than our ability to remove military resources from an area of active operations. The claims of South Viet- 
namese who did not wish to live under a communist regime must also receive consideration. What provision would the United States make for them?

In short, an official request for withdrawal, even if backed by unverified claims of widespread South Vietnamese support, should not necessarily result in cessation of United States military action or the delivery of all or part of South Viet Nam to communist control. Issues are involved which extend far beyond simply clearing South Viet Nam of Northern troops and Northern-sponsored insurgents. Possible alternatives might include support of a basically anti-communist South Vietnamese government in a loose federation along the lines of the former French administrative subdivisions. Or the United States might seek direct international control of the area-a regime similar to a United Nations trusteeship. The various proposals for "neutralization" of South Viet Nam might be compatible with such a regime. Otherwise, we would probably have to strengthen United States forces in South Viet Nam to prop up a wavering government and achieve whatever policies United States officials now have in view.

Apart from the difficulties invited by the Memorandum's emphasis on a continuing request for assistance, its frequent mention of an "armed attack" upon South Viet Nam bogs us down in a sterile dispute concerning unverifiable factual details. Those with information about the nature and scope of communist subversive military operations will recognize the Administration's basic statements of fact as correct. There is, however, a "credibility gap," and many intelligent and influential persons have not, and will not, accept in detail the facts offered by the Administration. Thus by emphasizing an "armed attack" as the universal solvent of the "legality" of United States assistance, the State Department permits critics of our policy to play upon the factual doubts of the American public. Indeed, the failure to link United States policy-making with a consistent effort to encourage and support decision-making by the general community concerning Viet Nam allows critics to portray United States policy as essentially destructive of international order, whereas in fact the United States policy consistently supports that order. This failure stems from neglect of the constitutive function of law.

22. Aggression from the North: The Record of North Viel-Nam's Campaign to Conquer South Viet-Nam, 52 DeP'T STATE BULL. 404 (1965), appearing also in SENATE Co:sas. ON Foreign Reiations, 89th CoNg., 2D Sess., Background Inforastion Relating to SOUTHEAST ASIA AND VIET NAM 171 (Comm. Print 1966) (less photos, maps and appendices); Carver, supra note 20, which contains an excellent and apparently highly accurate statement of the degree of North Vietnamese control over the Viet Cong. 
There is too little emphasis in the Memorandum, apart from the concentration upon Article 51, of the relationship of the United States action in Viet Nam to the shifting functions of the United Nations. The State Department's comments on this relationship reflect much of the Memorandum's philosophy: ${ }^{23}$

... The conclusion is clear that the United States has in no way acted to interfere with United Nations consideration of the conflict in Viet Nam. On the contrary, the United States has requested United Nations consideration, and the Council has not seen fit to act. ...

The United States' legal case would be stronger had we not confined ourselves to filing the required reports with the Security Council but had pressed more vigorously for United Nations participation. The United Nations position, as described by Secretary General U Thant, has been that the United Nations can do nothing because North Viet Nam and Red China will not appear before it.24

An advocate supporting United States policy might urge that the effective, although not formally stated, functions of the United Nations are in process of change; that membership in that Organization has never precluded all uses of force by members except in cases of armed attack, and that the power relationship of the United States to the United Nations Organization shifts with the functions of that Organization and the interrelationships of its members, particularly the more recent ones.

Despite the several provisions in the Charter for peace supervision and enforcement, the major function of the United Nations in the past decade has been "rheostatic" activity-the diffraction of coercive features of policy exchanges and the projection of these upon a verbal level in which persuasive features can dominate. The power of the United States, and of other countries with an interest in both stability and moderately paced change, may be utilized effectively by furnishing "interim sustaining action" until those rheostatic functions can be activated. In Viet Nam the interim sustaining military operations of the United States have been protracted because the two Asian aggressors involved are unwilling to appear before the United Nations to have their operations exposed to the view and judgment of the general community.

This is not to suggest that the United States has any "policing" functions in the general community. To suggest a broad mission such

23. Memorandum 479.

24. New York Times, April 7, 1966, p. 13, col. 1. 
as this, or a mission to make the world safe for "democracy," "diversity," "experiment" or any other reflection of an American way of life to be established for others, might be to encourage the "arrogance of power" which we all seek to avoid. But states having the power to support a viable world order of which most of the people of the world approve should shape their policies to support the institutions by which this order can be maintained-in this case the various organs of the United Nations concerned with peacekeeping. The United States action in Viet Nam, when viewed as "interim sustaining action" pending mobilization of more extensive efforts, military and otherwise, by the general community, should not depend for its legitimacy upon the well-documented "armed attack" by North Viet Nam. A threat to the peace is involved which ultimately will require action by the general community, and interim action by the United States is an indispensable prerequisite to an effective international solution. 